\title{
A NARRATIVE PATTERN AND ITS ROLE IN SOURCE CRITICISM
}

\author{
Joel S. Baden \\ Yale University
}

\begin{abstract}
The narrative portions of the Pentateuch (and the Deuteronomistic History) betray a consistent pattern in which commands are fulfilled by the same verb, in the same binyan, in the waw-consecutive, with virtually no intervening text. Because the pattern is uniform across all books and sources, it is shown that when the pattern does not function as expected, we are justified in looking for a source-critical seam. Most importantly, source-critical disputes over the precise demarcation of textual blocks can be resolved by means of this pattern.
\end{abstract}

\section{DEFINING THE PATTERN}

The purpose of this paper is to demonstrate that there is a well-defined syntactical pattern in the narrative portions of the Pentateuch, and that recognition of this pattern can be useful in correctly determining source-critical seams in the text. ${ }^{.}$The ubiquity of this pattern is such that it has gone essentially unrecognized as a formal aspect of Biblical Hebrew style. A representative example from a well-known passage will demonstrate the basic structure. Genesis 12:1 begins with the famous command לִ and continues with Yahweh's promise to Abram. Yahweh finishes speaking at the end of 12:3, at which point Abram immediately fulfills the initial command: This immediate action has been attributed to Abram's steadfast obedience to God's will; ${ }^{2}$ in fact, as we shall see, it is nothing more than a standard biblical trope for the fulfillment of a command. In this example, we can already see the form of the pattern: a command issued in the imperative, followed by the remainder of the speech between the two characters, and then the immediate fulfillment of the command, using the same verb, in the same binyan, in the waw-consecutive.

\footnotetext{
' That is, those literary loci at which one source changes to another, or a secondary insertion is found; the pattern itself remains the same across the entirety of the Pentateuchal text (see section 2 below), and indeed it is this very stability that permits the source-critical analysis proposed herein. The author wishes to thank Benjamin Sommer and Baruch Schwartz for their support and advice in the writing of this paper.

${ }^{2}$ G. von Rad, Genesis (Philadelphia: Westminster, 1972), p. 161; N. Sama, The JPS Torah Commentary: Genesis (Philadelphia: Jewish Publication Society, 1989); p. 90; G. W. Coats, Genesis with an Introduction to Narrative Literature (Grand Rapids, Mich.: Eerdmans, 1983), p. 100. See the valuable caution against placing such emphasis on Abram's actions in C. Westermann, Genesis 12-36 (Minneapolis: Fortress, 1995), p. 152.
} 
An important limit must be established before continuing to develop this pattern and its relevance for pentateuchal studies. We should not necessarily expect to find this pattern after every imperative in the Pentateuch. Rather, we find the pattern used when the biblical author chooses to narrate the direct fulfillment of a command. There are, to be sure, numerous places in the text where this is not the author's intention, and where we should therefore not expect to find the pattern used. Sometimes the character to whom the command is addressed refuses to obey, for example, Gen 19:16, when the angels command Lot to leave the city, but he tarries. Sometimes the author chooses to narrate the story in such a way that the fulfillment of the command is only assumed, rather than explicitly stated, as in Gen 45:1, when Joseph commands his attendants to leave him with his brothers, and we are not explicitly told that they obey, but rather that "there was no one else about when Joseph made himself known to his brothers." But when the author specifically wants to narrate the fulfillment of the command, the pattern we see exemplified in Genesis 12 is the standard formula by which he does so.

It is important also to note the other standard trope by which the fulfillment of a command is narrated: the clause and its variants, known particularly from the priestly source. ${ }^{3}$ Compared to the pattern observed here, however, these stock phrases are relatively scarce. In passages where immediate fulfillment is intended, they occur only ten times in the Pentateuch, compared to more than ninety for our pattern.

Two further details of the pattern are also worth noting. Approximately twenty times in the Pentateuch, there is a brief bit of narration before the fulfillment of the command. This is typically nothing more than a little action necessary to advance the plot to the point where the character can effectively fulfill the command. For example, in Gen 30:3, Rachel tells Jacob to take her maidservant Bilhah and sleep with her. While the pattern suggests that the fulfillment of her command is the first thing that should happen when she has finished speaking, the narrator takes a few words to tell us, in $30: 4$, "So she gave him her maid Bilhah as a concubine." Then Jacob sleeps with her, as he was instructed. As soon as the necessary action has been concluded, the pattern picks up as expected.

We also find that when a character issues more than one command, sometimes only one is fulfilled as expected according to the pattern. An example of this is found in 2 Sam 18:30, when David says to Ahimaaz, "Step

${ }^{3}$ Compare Exod 14:4; Lev 8:4, et al. 


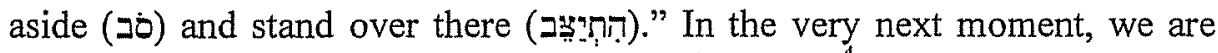
told that "he stepped aside (ב-.". and waited (

These small refinements to the pattern are relatively simple and easy to spot, and should not detract from the overall point. This pattern, even in only its most basic form, is frequent enough in the Pentateuch and on into the Deuteronomistic History, to be worthy of notice.

\section{THE EXTENT OF THE PATTERN,}

This pattern occurs over 90 times in the Pentateuch, and over 115 times in Joshua through Kings. ${ }^{5}$ It is found in every book of the Pentateuch, though it is relatively under-represented in Leviticus, because so much of the book is legislation rather than narrative. Furthermore, unlike many stylistic features, the pattern is not predominantly used by any one source of the Pentateuch, which suggests that it was simply a standard feature of Biblical Hebrew narrative style. Whether one continues to subscribe to the classical Documentary Hypothesis or follows an alternative model, the pattern is well-distributed across the various compositional layers, as will be seen below. The example above from Genesis 12 is classically assigned to J; examples can be found in passages traditionally assigned to $P, E$, and $D$ as well:

P: In Exod 9:8, God commands Moses and Aaron 17 ; this command is fulfilled after God has finished speaking in 9:10, $7 \pi_{1}:{ }^{6} .{ }^{6}$

E: God gives Moses the command in Num 21:8 to make the bronze ser-

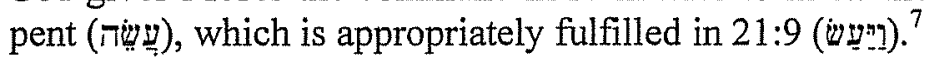

\footnotetext{
${ }^{4}$ See also Gen 19:34-35 in which it is the first verb that varies.

${ }^{5} \mathrm{~A}$ list of the occurrences in the Pentateuch comprises the following: Gen $8: 16-18 ; 12: 1-4 ; 15: 9-10 ; 16: 2-$ $4 ; 19: 34-35 ; 22: 2-3$ (twice); 24:2-9, 31-32; 25:31-33, 33; 26:16-17; 27:3-5, 4-5, 9-14 (twice), 21-22, $25,26-27$ (twice); $29: 27-28 ; 30: 3-4 ; 33: 11 ; 37: 22-23,32-33 ; 38: 11,25-26 ; 40: 8-9 ; 42: 2-3 ; 43: 11-15$, $16-17,31-32 ; 45: 4 ; 47: 16-17,31 ; 48: 9-10 ; 50: 6-7$; Exod 2:9; 4:3, 4, 6, 7, 19-20, 27; 7:9-10; 8:1-2, 1213 (twice), 24-26; 9:8-10 (twice), 22-23; 10:1-3, 12-13, 17-18, 21-22; 14:16-24 (see section 4 below), 26-27; 16:16-17, 23-24, 33-34; 19:24-25; 24:1-9 (see section 4 below), 12-13; 32:2-3 (twice), 7-15 (see section 5 below); 34:1-4; Lev 9:2-5 (twice), 7-8; Num 3:15-16, 40-42; 7:5-6; 11:16-24 (see section 4 below); 12:4; 13:2-3, 17-22; 16:17-18, 24-26 (twice; see section 5 below); 17:11-12, 17-21; 20:8-10 (twice), 26-28; 21:8, 8-9; 22:35; 23:5-6; 27:18-22; Deut 31:14, 19-22 (twice); 32:49-34:1 (see section 4 below). Though this list aims to be exhaustive, there are almost certainly examples that I have inadvertently missed.

${ }^{6}$ Insofar as every model of pentateuchal composition recognizes the existence of and basic integrity of $P$, there is near-universal agreement as to the assignment of this and other priestly passages.

${ }^{7}$ Though the question of the existence of the $\mathrm{E}$ source remains prominent in pentateuchal studies, even those scholars who deny an independent $E$ source agree that the unit of Num 21:4-9 is a unity, whether Deuteronomic or redactional. Compare E. Blum, Studien zur Komposition des Pentateuch (Berlin: Walter de Gruyter, 1990), pp. 122-123; C. Levin, Der Jahwist (Göttingen: Vandenhoeck \& Ruprecht, 1993), p. 379; R. Achenbach, Die Vollendung der Tora (Wiesbaden: Harrasowitz Verlag, 1993), pp. 347-352; W.
} 
Though Deuteronomy is not very fertile ground for the pattern, as so much of it is descriptive, we find it even in D. ${ }^{8}$ In Deut $31: 19$, God com-

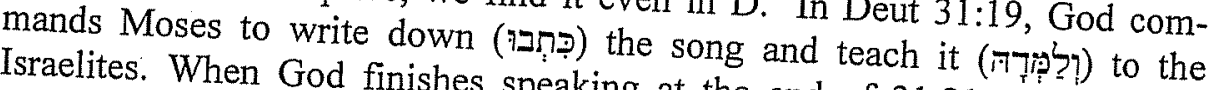
Israelites. When God finishes speaking at the end of $31: 21$, as expected,

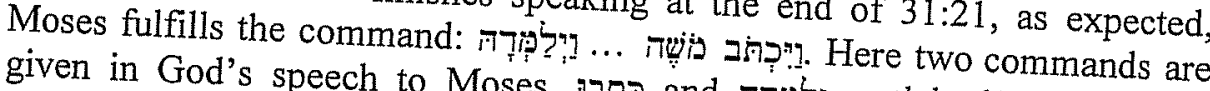

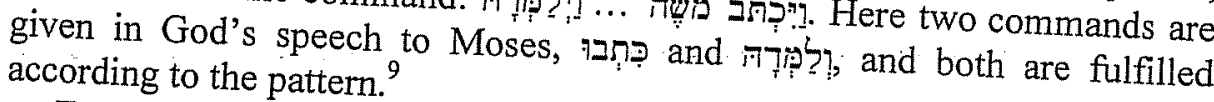

Every example cited thus far has involved a divine command, but this does not represent the full extent of the pattern. It is also found in commands between humans, and in what we may call indirect divine command. For an example of the first class, see, for example, Gen 27:21-22. The majority of the examples of the pattern involving human command come from Genesis, and, not surprisingly, nearly all are from texts classically assigned to $\mathrm{J}$ or $\mathrm{E}$. A significant concentration are found specifically in the narrative of Jacob stealing Esau's blessing in Genesis 27.

The smallest category of the three, indirect divine command, describes those instances where a divine command is given through an agent of God. With the exception of one occurrence in Numbers, all the examples of this type are from Exodus, and in every case the agent is Moses. An example is Exod 8:1-2, a $\mathrm{P}$ text, in which God issues a command to Aaron through
Moses, and Aaron fulfills it as expected.

The pattern is so common a feature in the narrative portions of the Pentateuch that it has hardly been noticed, and never adequately defined. Obviously, there are no hard and fast rules governing stylistic usage in the Hebrew Bible, and for that reason we should not be surprised to find that there are exceptions to the pattern, though they are remarkably few. Before going on to apply this pattern to source criticism, it is important to recognize
those few times that the pattern seems not to function as expected.

\footnotetext{
Johnstone, "The Use of the Reminiscences in Deuteronomy," in Abschied vom Jahwisten (ed. J. Gertz, K

${ }^{8}$ The source $M$. Witte; Berlin: Walter de Gruyter, 2002), pp. 267-268. because of its yocabulary and its relationshipy $(31: 16-22)$ is debatable. Though many ascribe it to JE the theory of S. R. Driver, Introduction to the Literature of Moses, one must give serious consideration to pp. 72, 96-97, that while it may have originally belonged to Old Testament (New York: Meridian, 1957), Deuteronomic editor at the same time as the song. See also an older hand, it was inserted into this text by a Hexateuch According to the Revised Version (London: Longmans, Carpenter and G. Harford-Battersby, The

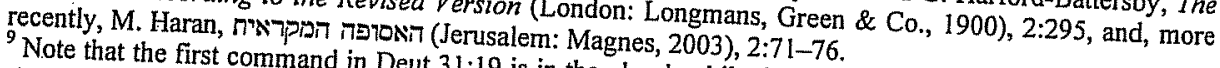
singular. While this could simply be an is in the plural, while the second is'singular; in $31: 22$, both are [Philadelphia: JPS, 1996], p. 295) points out that the commay (The JPS Torah Commentary: Deuteronomy who becomes involved not immediately, but rather in Deut 32:44.
} 


\section{THE EXCEPTIONS TO THE PATTERN}

There are two main ways in which the pattern can break down: either the fulfillment seems to be narrated, but the verb does not match that of the command, or there is some unexpected material intervening between the command and fulfillment. True exceptions to the pattern occur only. in the first of these cases, in which the verbs of command and fulfillment do not match.

In Gen 31:46 Jacob tells his kinsmen, "Gather ("לקט) stones." The next clause, however, reads, "They took (Iיז) stones," violating the pattern. This may be the result of a text-critical error: for the fulfillment, the LXX reads as we would expect, $\sigma v v \varepsilon \dot{\lambda} \varepsilon \xi \xi \alpha v$, translating 10 1. ${ }^{10}$

In Num 22:8, Balaam says to the elders of Moab and Midian, "Spend the night (לינ) here." The fulfillment of this command, however, reads, "They

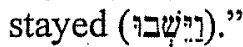

In Num 23:16, Yahweh says to Balaam, "Return (שיו) to Balak." We expect to read, "He returned (וישב) to him." Instead, the fulfillment in 23:17 is, "He came (Iי (יָז) to him." This example is particularly vexing because earlier in the same chapter, in 23:5-6, we have the exact same command, with the expected fulfillment according to the pattern. ${ }^{11}$ Though the source-critical analysis of the Balaam narrative as a whole is less than certain, ${ }^{12}$ we should expect these narrative structures to be from the same source; even if one argues that the two pairs are from different sources, they should still be internally consistent.

There is no apparent explanation for these types of exceptions. ${ }^{13}$ But they are so few as to make hardly a dent in the number of times the pattern works

\footnotetext{
${ }^{10}$ It is unclear from this, however, which should be considered the original reading. Perhaps the LXX translators, familiar with the expected pattern, simply replaced the reading of the fulfillment in the MT with the appropriate verb according to the pattern. Alternatively, and equally plausibly, an MT scribe misread the command as the more common verb IחP and, expecting the pattern to function normally, rendered the fulfillment accordingly.

"Again, there is a text-critical issue here, as the LXX reads $\alpha \pi \varepsilon \sigma \tau \rho \alpha \dot{\alpha} \varphi \eta$, translating $ב$ ' But in this case, it is probable that the LXX is harmonizing the second pair in Num 23:16-17 with the first in 23:5-6, leaving us with the lectio difficilior of the MT as the most likely original reading.

${ }^{12}$ See A. Rofé, בסלעם (Jerusalem: Simor, 1979).

${ }^{13}$ Although there is a well-observed tendency in biblical narrative toward variation rather than verbatim repetition (cf. R. Alter, The Art of Biblical Narrative [New York: Basic, 1981], pp. 97-99; M. Sternberg, The Poetics of Biblical Narrative: Ideological Literature and the Drama of Reading [Bloomington, Ind.: Indiana University Press, 1987], pp. 390-393), it is difficult to claim that in these three passages (and only in these three) that tendency is responsible for the deviation from the regular pattern. It is possible, however, that the verbs of motion were considered so substantially similar as to be virtually interchangeable, at least for the purposes of the pattern observed here (this was suggested to me by Benjamin Sommer, personal communication).
} 
correctly; in fact, the three examples above are the only three like this in the Pentateuch. As was already noted, they break only the rule that the verb must be from the same root; otherwise, they conform to the pattern, in that they are of the same binyan, and follow immediately upon the conclusion of the speech which contains the command, that is, there is no intervening material between the imperative and its fulfillment.

When we become aware of the presence and extent of the pattern described above, it becomes clear that the exceptional narrative moments are not those in which a character fulfills a command immediately, as in Gen $12: 4$, but rather those in which immediate fulfillment does not occur as expected. It is those cases that are narratively and stylistically marked, and that deserve greater exegetical attention. Thus there is value in the mere recognition of the pattern. Beyond that, however, awareness of the pattern can be put to valuable service in the field of source criticism, as will be demonstrated below.

\section{SOLVING EXCEPTIONS THROUGH SOURCE CRITICISM}

The pattern is common enough, and consistent enough, that when it appears to break down, either because the fulfillment does not match the command, or because there is some intervening material between the command and the fulfillment, we should look for a means of explaining this apparent deviation. More frequently than not, source criticism provides the explanation for these breakdowns. I have taken the following examples from passages where the source-critical division is agreed on by the majority of scholars, of both the classical and alternative schools, so as to provide something of a control for the argument.

\subsection{Exodus 24:1-9}

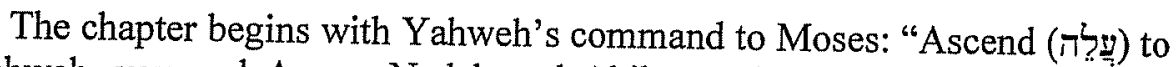
Yahweh, you and Aaron, Nadab and Abihu, and seventy of the elders of Israel." Yahweh continues to speak until the end of $24: 2$, at which point we expect Moses to fulfill the command. But for this we have to wait until 24:9. Verses 3-8 contain the narrative of the people accepting the covenant, and Moses sacrificing and reading aloud the terms of the covenant to the people. In 24:9, we get precisely what we would have expected to follow on $24: 2$ : "Moses and Aaron, Nadab and Abihu, and seventy of the elders of Israel ascended (y)." The evidence of the pattern conforms to the generally agreed 
scholarly view that Exod $24: 1-2,9-11$ and 3-8 are from two different sources. ${ }^{14}$ This example (and those that follow) also demonstrates an important point: the only time that we find intervening material between the command and its fulfillment is when there is a source-critical division. As shown in section 3 above, there are places where a different verb is used in the fulfillment even within the same source. But never does a biblical author present a command, then turn to some other unrelated bit of material before narrating the explicit fulfillment of the command. When we encounter examples such as these, it is an exceptionally strong indication of a sourcecritical break.

\subsection{Exodus 14:16-21}

In Exod 14:16, Moses is commanded to stretch (بְטֵ) his arm over the sea, so that the Israelites may cross on the dry land. God's speech continues until the end of $14: 18$, so we expect the command to be fulfilled at the beginning of 14:19. But in 14:19-20 the direct speech ends, and we have a narrative description of the movements of the angel of God and the pillar of cloud. It is only with 14:21 that we have the expected fulfillment of the command in 14:16: "Moses stretched (ט:!) his arm over the sea." Though the precise composition of 14:19-20 is uncertain, scholars are agreed that they are non-priestly, while $14: 16-18$ and $21-23$ are from $P .{ }^{15}$ The pattern is thus

\footnotetext{
${ }^{14}$ Some scholars attribute Exod 24:3-8 to D (cf. E. Nicholson, God and His People [Oxford: Clarendon, 1986], pp. 164-178); others refuse to ascribe it to a specific source at all, seeing it as a later, independent addition (cf. M. Noth, Exodus: A Commentary [Philadelphia: Westminster, 1962], pp. 197-199; M. Noth, $A$ History of Pentateuchal Traditions [Englewood Cliffs, N.J.: Prentice Hall, 1972], pp. 31 n. 115, 270; A. Jenks, The Elohist and North Israelite Traditions [Missoula, Mont.: Scholars, 1977], pp. 46, 49; E. Blum, Studien, pp. 91-92, 99; J. C. Gertz, Tradition und Redaktion in der Exoduserzählung [Göttingen: Vandenhoeck \& Ruprecht, 2000], p. 302; J. Van Seters, The Life of Moses [Louisville, Ky.: Westminster John Knox, 1994], p. 282). Traditionally, these verses belong to E (cf. J. E. Carpenter and G. HarfordBattersby, The Hexateuch, 2:118-119; A. McNeile, The Book of Exodus [London: Methuen, 1908], p. 31; S. R. Driver, The Book of Exodus in the Revised Version [Cambridge: Cambridge University, 1929], pp. xxvii, 252-254; O. Eissfeldt, The Old Testament: An Introduction [New York: Harper \& Row, 1965], p. 201) For discussion and overview of the scholarship on this issue, see B. Childs, The Book of Exodus (Louisville, Ky:: Westminster John Knox, 1974), pp. 500-501, and C. Houtman, Exodus (Leuven: Peeters, 2000), 3:286.

${ }^{15}$ The precise assignment of the non-priestly material is debated; J. Van Seters, Life of Moses, pp. 131, 133, for example, ascribes Exod 14:19-20 to J; M. Weinfeld, Deuteronomy and the Deuteronomic School (Winona Lake, Ind.: Eisenbrauns, 1992), p. 34, ascribes them to E. Agreement as to the general division here is, however, certain. Compare J. E. Carpenter and G. Harford-Battersby, The Hexateuch, 2:101-102; A. McNeile, Book of Exodus, p. 21; S. R. Driver, Book of Exodus, pp. xxv, 118; R. H. Pfeiffer, Introduction to the Old Testament (New York: A \& C Black, 1948), pp. 145, 170; M. Noth, Exodus, pp. 103, 114; M. Noth, Pentateuchal Traditions, p. 269; J. Wellhausen, Die Composition des Hexateuchs und der historichen Bücher des Alten Testaments (Berlin: Walter de Gruyter, 1963), p. 76; G. Fohrer, Überlieferung und Geschichte des Exodus (Berlin: Walter de Gruyter, 1964), p. 99; B. Childs, Book of Exodus, p. 220; W.
} 
ostensibly disrupted in the canonical text, but is restored when the sourcecritical division is correctly accomplished.

\subsection{Deuteronomy 32:49-34:1}

This is the most striking example of this type, in that the intervening material comprises an entire chapter. Deuteronomy 32:49 has Yahweh commanding Moses, "Go up (עילֶ) to the mountain," where Moses is to die. Yahweh continues to speak to Moses until the end of the chapter, 32:52. ${ }^{16} \mathrm{At}$ this point, Moses ought just to ascend the mountain wordlessly, showing the kind of "obedience" we know from the Abram story in Genesis 12. Instead, Moses recites a poem, which takes up the entirety of Deuteronomy 33. But in the first words of Deuteronomy 34, "Moses went up ('D"1)." Deuteronomy 32:49 and 34:1 are universally assigned to $P$, while the Blessing of Moses in Deuteronomy 33 is recognized as a much earlier collection of tribal sayings. ${ }^{17}$

\subsection{Numbers 11:16-24}

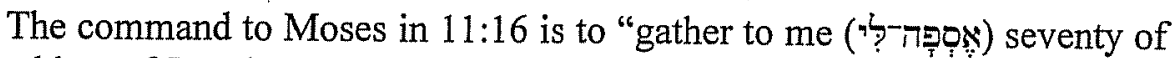
the elders of Israel." They are to be brought to the Tent of Meeting so that Yahweh can imbue them with some of Moses' prophetic spirit. Given the expected pattern of command and fulfillment, it is therefore somewhat jarring when, in 11:18-23, Yahweh and Moses engage in heated conversation on the unrelated topic of providing meat for the Israelites. It is only in 11:24b that we read the fulfillment of the command in 11:16: "He gathered (70 sion of provisions for the people, though still within the formal framework of the dialogue between Moses and Yahweh, suggests that the pattern has been broken here. Further confirmation is provided by the brief narrative in

H. C. Propp, Exodiss 1-18 (New York: Doubleday, 1998), pp. 462, 479-480; L. Schmidt, Studien zur Priesterschrift (Berlin: Walter de Gruyter, 1993), pp. 19-34. Those who do not subscribe to the classical model see essentially the same textual divisions here, although with varying nomenclature; compare C. Levin, Jahwist, p. 345; J. C. Gertz, Tradition, pp. 195-206.

${ }^{16}$ There are differences of opinion over the assignment of Deut 32:50-52, because of the reference to the episode at Meribath-Kadesh; even if those verses are removed as a later interpolation, however, that only brings the command in 32:49 and its fulfillment in 34:1 closer together. I am not convinced that 32:50-52 should be separated from $32: 49$, but it is certain that $32: 49$ belongs with $34: 1$, whether $32: 50-52$ accompany it or not.

${ }_{17}^{17}$ Compare S. R. Driver, Deuteronomy (Edinburgh: T\&T Clark, 1901), p. 389; G. von Rad, Deuteronomy (Philadelphia: Westminster, 1966), pp. 204-205; R. D. Nelson, Deuteronomy (Louisville: Westminster John Knox, 2002), p. 386. 
11:24a, in which Moses reports the words of Yahweh to the people. This can only refer to the discussion of the meat in 11:18-23, not to the gathering of the elders in 11:16-17, and therefore cannot be acceptable as narrative necessary for the furthering of action between command and fulfillment (see above, section 1). The division of Numbers 11 into two distinct strands, each of which tells an independent story (one of the people demanding meat; one of the elders being given the prophetic spirit) is acknowledged in both classical and alternative models of composition, and the verse division is the same: $11: 16-17,24 b-30$ are part of the story of the elders, and the intervening verses are part of the meat narrative. ${ }^{18}$

\subsection{Exodus 7:19-20}

In all the above examples, there is intervening material between the command and its fulfillment, which is always the result of the combination of separate sources. Though the command and fulfillment can be mismatched for unknown reasons, as shown in section 3, we also find at least one place where the command and fulfillment do not match properly due to a source-critical issue. In Exod 7:19, Yahweh tells Moses to tell Aaron, "Take (חק) your rod and stretch (Iְט) your arm over the waters of Egypt." The rest of the verse is the conclusion of Yahweh's speech to Moses, so we expect the command to be fulfilled immediately. Instead, we read, "Moses

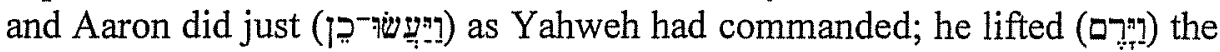
rod and struck (7י1) the waters which were in the Nile." Two issues present themselves: first, the stock phrase

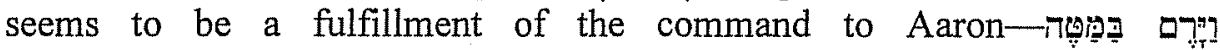
$7: y$ - but one that does not match the preceding command.

Source criticism provides the solution. The stock phrase in 7:20a is the fulfillment of the command in 7:19; this is why we read that Moses and Aaron did as God commanded: Moses transmitted the message, and Aaron

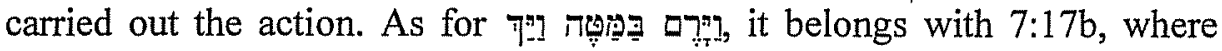

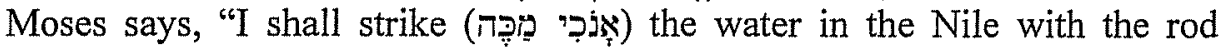

\footnotetext{
${ }^{18}$ Classically, the meat narrative is from $\mathrm{J}$, and the prophetic narrative from $\mathrm{E}$; compare R. H: Pfeiffer, Introduction, p. 171; C. A. Simpson, The Early Traditions of Israel (Oxford: Blackwell, 1948), p. 629; M. Noth, Numbers: A Commentary (Philadelphia: Westminster, 1968), pp. 87-88, M. Noth, Pentateuchal Traditions, p. 273; A. Jenks, Elohist, pp. 54-55. For discussion of the debate, compare B. Sommer, "Reflecting on Moses: The Redaction of Numbers 11," JBL 118 (1999): 603-609. For the similar analyses of non-documentary scholars, compare E. Blum, Studien, p. 78; C. Levin, Jahwist, p. 374; R. Achenbach, Vollendung, pp. 283-284; A. G. Auld, "Samuel, Numbers, and the Yahwist-Question," in Abschied vom Jahwisten (ed. J. Gertz, K. Schmid, and M. Witte; Berlin: Walter de Gruyter, 2002), pp. 239-240. J. Van Seters, Life of Moses, pp. 228-234, sees no break here.
} 
which is in my hand." As this is not a command, it does not demand fulfillment according to the pattern, but 7:19 comes close nevertheless. As we should expect, virtually all source critics agree that the command in 7:19 and the stock phrase in 7:20a are from $P ; 7: 20 \mathrm{~b}$ and its related verses are from $\mathrm{J}$ (or non-P, for those scholars who reject the classical J source). ${ }^{19}$

\section{RESOLVING SOURCE-CRITICAL DISPUTES THROUGH THE PATTERN}

In the preceding examples, a commonly accepted source-critical division intersects with a textual divison based solely on the application of the pattern. This reinforces both the existence of the pattern and the correctness of the source-critical division. But in doing this we achieve only half of what is possible. To this point, we have seen that what looks like a malfunction of the expected pattern can be resolved by dividing the sources. The more important task at hand, however, is to do the reverse: to attempt to resolve troublesome source-critical problems by using the pattern.

\subsection{Exodus 32:7-15}

The first six verses of this chapter famously narrate the creation of the golden calf. In 32:7, Yahweh tells Moses of this development, commanding him to descend (לר). Yahweh then continues to speak until 32:14; in $32: 15$, as expected, Moses descends (7רי? 1 ). It is commonly accepted that $32: 15$ continues the narrative from $32: 1-6$, but it is widely claimed that some part of 32:7-14 is from a different source, or is a later addition to the text altogether. Some scholars argue that the insertion covers the entirety of 32:7-14. . $^{20}$ This opinion is based largely on the notion that Moses' sudden burst of anger at seeing the calf in 32:19 is incomprehensible if Yahweh had already told Moses what was going on in 32:7-8. If we consider this a real problem (though it hardly seems insurmountable), then removing 32:7-14

\footnotetext{
19 The broad concurrence on this source division is evident in the diverse group of scholars who agree on its particulars: S. R. Driver, Exodus, pp. xx, 55; B. Childs, Exodus, p. 131; W. H. C. Propp, Exodus, p. 287; J. Van Seters, Life of Moses, pp. 77, 110-111; M. Noth; Pentateuchal Traditions, pp. 30, 268; M. Noth, Exodus, pp. 62, 73; C. Levin, Jahwist, p. 336; J. C. Gertz, Tradition, p. 80. E. Blum ("The Literary Connection between the Books of Genesis and Exodus and the End of the Book of Joshua," in A Farewell to the Yahwist? [ed. T. B. Dozeman and K. Schmid; Atlanta: Scholars, 2006], p. 94) is practically alone in seeing Exod 7:19-20 as belonging entirely to $P$.

${ }^{20}$ See J. E. Carpenter and G. Harford-Battersby, The Hexateuch, 2:130-131; A. McNeile, Book of Exodus, p. 37; A. Jenks, Elohist, pp. 50-51; E. Blum, Pentateuch, p. 73; H.-C. Schmitt, "Die Erzählung vom Goldenen Kalb Ex. 32* und das Dtr Geschichtswerk," in Rethinking the Foundations (ed. S. L. McKenzie and T. Römer; Berlin: Walter de Gruyter, 2000), pp. 235-250; J. Loza, "Exodus xxxii et la redaction JE," VT 23 (1973): 31-55.
} 
solves it. But what would remain in the now separated block of text would have its problems also, primarily the repeated 1 in $32: 7$ and 9. And if the secondary material includes $32: 7$, then we lose the connection between $32: 7$ (לר)

The other common conclusion is that the division starts at 32:9. ${ }^{21}$ This immediately solves the problem of the double speech introducer. Furthermore, it takes into account the thematic distinction of 32:9-14, which are a self-contained discussion between 'Yahweh and Moses, and which, unlike $32: 7-8$, contain no reference to the golden calf. The pattern stands in support of placing the division at 32:9; if the break comes at 32:9, rather than 32:7, the pattern is preserved. ${ }^{22}$ We should be wary of breaking up good examples of the pattern for source-critical purposes; I have yet to find a place where this is necessary.

\subsection{Genesis 26:2-6}

The beginning of Genesis 26 is a complicated little passage for source criticism. It begins with the narrative notice that Isaac went to Gerar because of a famine. In 26:2, Yahweh appears to him and tells him not to go to Egypt, but to "dwell (j) in the land which I designate to you," and furthermore, in 26:3, "reside (7i: in this land." This is followed by a standard promise formula, like that of Genesis 12 and elsewhere, which concludes in 26:5. Verse 6 then tells us, "Isaac stayed (בשֶ:"I) in Gerar." Perhaps because of the confusing sequence of verbs, scholars are divided over how to assign these verses to sources. It is commonly thought that the promise formula here is secondary. But where precisely does the formula, and therefore the presumed secondary addition, begin? According to some, the addition begins in $26: 3 \mathrm{~b}$, with "for I will give to you and your seed all these lands."

\footnotetext{
${ }^{21}$ See S. R. Driver, Exodus, p. xxviii; M. Noth, Exodus, p. 242 (cp. however M. Noth, Pentateuchal Traditions, p. 31 n. 113 in which he places the break at Exod 32:7); J. Wellhausen, Composition, p. 91; B. Childs, Exodus, p. 559; J. Van Seters, Life of Moses, pp. 293-295; E. Nicholson, The Pentateuch in the Twentieth Century (Oxford: Clarendon, 1998), pp. 129, 173, 191-192; B. Sommer, "Translation as Commentary: The Case of the Septuagint to Exodus 32-33," Textus 20 (2000): 45-46.

${ }^{22}$ Note that if in fact an insertion has occurred in Exod 32:9-14, it must have taken place at an early stage in the composition of Exodus 32, since the parallel text in Deut 9:12-14, which is based on the narrative of Exodus 32, contains the same double speech-introducer as well as the same sudden change in theme.

${ }^{23}$ See A. Kuenen, An Historico-Critical Inquiry into the Origin and Composition of the Hexateuch (London: Macmillan \& Co., 1886), p. 259; O. Eissfeldt, The Old Testament, p. 200; G. von Rad, Genesis, p. 270; J. A. Emerton, "The Origin of the Promises to the Patriarchs in the Older Sources of the Book of Genesis," VT 32 (1982): 18; J. Blenkinsopp, The Pentateuch (New York: Doubleday, 1992), p. 122; C. Levin, Jahwist, pp. 201-206; E. Blum, Die Komposition der Vätergeschichte (Neukirchen-Vluyn: Neukirchen Verlag, 1984), pp. 362-363; D. Carr, Reading the Fractures of Genesis (Louisville: Westminster John Knox, 1996), pp. 153-159.
} 
$26: 3 b-5$ are therefore removed as secondary, however, a problem emerges with the pattern: the commands in 26:2 and $3 \mathrm{a}$ (j) and fulfilled in 26:6 ( 2 wi:n), but not by the appropriate verb, or verbs.

The other solution sometimes offered is to start the division at the beginning of Gen $26: 2$, thereby attributing both commands to the secondary addition of the promise formula. ${ }^{24}$ This solves the problem of the broken pattern, as the commands are entirely removed as secondary; now 26:6 does not have to be a fulfillment of an imperative, but is rather a simple narrative notice: Isaac dwelt in Gerar. The division of the text at 26:2, then, conforms better to the pattern. ${ }^{25}$ In the previous example, we tried to preserve a functioning example of the pattern between Exod 32:7 and 15. In this example, we have tried a complementary move: dividing the sources in such a way that we are not left with a malfunctioning example of the pattern.

\subsection{Numbers 16:23-27}

The final example demonstrates the full extent of the usefulness of the pattern. In this case we are not deciding between competing source-critical divisions, but insisting upon an entirely new assignment of sources in an important pentateuchal passage.

The standard source-critical division of this part of Numbers 16 is to assign 16:16-24 to $P$, and 16:25-34 to non-P. ${ }^{26}$ The basic separation at work here is that between the dual stories of Korah and his clan and their rebellion, and Dathan and Abiram and their revolt. (Everyone agrees that in 16:24 and 27 the redactor has put all three names in the verse so as to more effectively combine the stories. So, for the bulk of scholarship, the redactor has added Dathan and Abiram to the P story of Korah in 16:24, and has added Korah to the E story of Dathan and Abiram in 16:27.)

This common source division, however, destroys not one, but two examples of the pattern. In Num 16:24, Yahweh tells Moses, "Speak (7ฐָּ to the

\footnotetext{
${ }^{24}$ See F. Delitzsch, A New Commentary on Genesis (Edinburgh: T\&T Clark, 1888-1894), pp. 138-139; J. E. Carpenter and G. Harford-Battersby, Hexateuch, 2:38; J. Wellhausen, Composition, p. 29; F. M. Cross, Canaanite Myth and Hebrew Epic (Cambridge: Harvard University, 1973), p. 273 n. 231 ; C. Westermann, The Promises to the Fathers (Philadelphia: Fortress, 1980), p. 129; E. Nicholson, Pentateuch, p. 106; E. Nicholson, God and His People, p. 112; H. Gunkel, Genesis (Macon, Ga.: Mercer University, 1997), p. 294.

${ }^{25}$ The possibility should not be discounted, however, that this passage is in fact a unity, and that the ostensible deviation from the pattern is in fact another example of the free interchange of verbs of motion, as in the exceptions noted in section 3 above (see n. 13).

${ }^{26}$ Representative of this view are M. Noth, Numbers, p. 121, and B. Levine, Numbers 1-20 (New York: Doubleday, 1993), p. 405.
} 
congregation: 'remove yourselves (העעלר) from around the dwelling of Korah, Dathan and Abiram." We expect this command to be fulfilled immediately. Instead, in 16:25, "Moses arose and went to Dathan and Abiram," with the elders in tow. Then, in 16:26, "he spoke (1יריר them, "move away (סרור) from the tents of these wicked men." Moses speaks

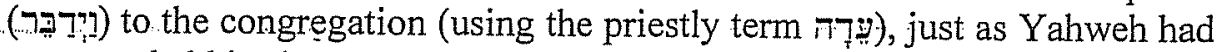
commanded him in 16:24; this should be considered the first example of the pattern. For some commentators, it is troubling that Moses does not repeat Yahweh's command to the people verbatim. ${ }^{27}$ There are enough other examples in the Bible of characters paraphrasing or rephrasing God's words, however, starting back in the garden of Eden in Genesis 3, that it is not a legitimate basis for compositional analysis. ${ }^{28}$ Moses' words, furthermore, achieve the desired effect in 16:27, to the letter: "they removed themselves (IיI) from around the dwelling of Korah, Dathan and Abiram." This is the perfect fulfillment of Yahweh's indirect command in 16:24, and is the second example of the pattern in this passage. With this information in hand, we can turn to the reconfiguration of the sources.

'The priestly source comprises Num 16:16-24, as virtually all commentators have concluded. But it resumes in 16:26-27a, where we have the double completion of the pattern from 16:23-24. All of this must belong to $P$.

What does this leave for the non-priestly strand? In Num 16:25, Moses goes to the tents of Dathan and Abiram, since they have refused to go to him in 16:12-14. And indeed, in 16:27b, Dathan and Abiram are standing at the entrance to their tents, because Moses and the elders are approaching. Both narratives now work independently, and the double occurrence of the pattern, entirely restricted to $\mathrm{P}$, is maintained. The only addition the redactor made in this section was to add the names Dathan and Abiram to the priestly narrative in both 16:24 and 27, but even there it is done somewhat clumsily. Note the singular pִin in 16:24 and $27 \mathrm{a}$, where it suggests a singular dwelling for all three characters. This is in contrast to $16: 27 \mathrm{~b}$, where Dathan and

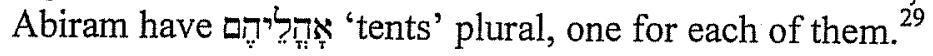

\footnotetext{
${ }^{27}$ For example, J. E. Carpenter and G. Harford-Battersby, The Hexateuch, 2:214.

${ }^{28}$ See the references to variation in biblical narrative in $n .13$ above.

${ }^{29}$ The use of the word 'Trin in Moses' instructions to the Israelites in Num 16:26 probably accounts for much of the scholarly misreading of the source division here, as it is assumed that the "tents" belong only to the non-priestly story of Dathan and Abiram. Yet the narrative itself makes clear that $16: 26$ cannot be from the non-priestly story. When the earth swallows Dathan and Abiram and their households, the people are still standing around them, and are terrified by the unexpected event (16:34). It is clear that they have not been warned to withdraw, nor done so (16:26-27); in fact, they have no foreknowledge of Dathan and Abiram's impending demise at all. This stands in contrast to the priestly narrative, in which the challenge of Korah and his men, and the test by which they are proven wrong, is very much a public event.
} 
Though others have come close to this conclusion, they have invariably missed the mark. Most use or slightly alter the standard division of Num 16:16-24 for P, and 16:25-34 for non-P. G. B. Gray, in his commentary on Numbers, impossibly assigns only the phrase "and he spoke to the congregation:" in 16:26 to $P$, leaving the rest of the verse to non-P. ${ }^{30}$ This was evidently done with the intention of preserving for $\mathrm{P}$ the priestly vocabulary in 16:26, but leaves us with a completely disconnected speech introducer which has nothing to do with what precedes or follows it in P. Driver, R. E. Friedman, and Blum recognize that 16:27a must belong to $P$, but miss 16:26 entirely. ${ }^{31}$

\section{CONCLUSION}

The pattern described in this paper is a stylistic trope found in the narrative portions of the Pentateuch and the Deuteronomistic History. As such, it was not forced on the biblical author, but rather was one choice among many for narrating command and fulfillment. What I have tried to demonstrate here is that when the choice was made to narrate the direct fulfillment of a command, this pattern was the nearly universal way in which the author did so. One of the ways that we can judge whether the observed pattern should be considered a rule is by noting those times that the pattern seems to be broken; the fact that in nearly every case the apparent malfunction of the pattern can be attributed to a source-critical break strongly suggests that the pattern has been correctly defined. With this information in hand, the pattern can in turn be used prescriptively, rather than merely descriptively: those times that the pattern malfunctions can be used as markers of source-critical divisions. Furthermore, as can be seen from the examples above, this pattern is useful across methodological lines; whether one adheres to the Documentary Hypothesis or a newer alternative, the pattern, by virtue of being common to all biblical narrative, can serve as a tool for analyzing source divisions. Proper attention to this narrative pattern, then, can add a perhaps more objective criterion in the study of source criticism, a field which has been accused, rightly or wrongly, of being largely subjective.

\footnotetext{
${ }^{30}$ G. B. Gray, Numbers (Edinburgh: T\&T Clark, 1903), pp. 202-207. He is followed in this by B. Levine, Numbers, p. 416. Compare also J. E. Carpenter and G. Harford-Battersby, The Hexateuch, 2:214.

${ }^{31}$ S. R. Driver, Introduction, p. 63; R. E. Friedman, The Bible with Sources Revealed (San Francisco: HarperOne, 2003), p. 270; E. Blum, Studien, p. 264 n. 131. More complicated, but similarly flawed, analyses can be found in C. Levin, Jahwist, p. 377; R. Achenbach, Vollendung, pp. 43-54.
} 